\title{
STUDI KOMPARATIF ASPEK PENGUKURAN KINERJA KEUANGAN SEBELUM DAN SELAMA PANDEMI COVID
}

\author{
Rahman Pura \\ STIEM Bongaya Makassar \\ sahman_aslam@yadoo.com
}

\begin{abstract}
Abstrak
Penelitian ini bertujuan untuk menganalisis perbedaan kinerja keuangan dari aspek solvabilitas dan profitabilitas sebelum dan selama pandemi covid. Penelitian dilakukan pada PT Telkomsel. Data dikumpul dengan teknik dokumentasi berupa laporan keuangan berdasarkan kuartal kesatu, kedua dan ketiga tahun 2019 dan tahun 2020. Teknik analis menggunakan uji Beda t Test dengan jenis pengujian Paired Samples T Test yakni membandingkan data sebelum pandemi covid (2019) dengan data selama pandemi covid (2020).

Hasil peenlitian menunjukkan nilai solvabilitas (DER) selama pandemi covid meningkat dibanding sebelum pandemi covid, sedangkan nilai profitabilitas (ROA) selama pandemi covid menurun dibanding sebelum pandemi covid. Kemudian terdapat perbedaan yang signifikan kinerja keuangan sebelum dan selama pandemi covid baik dari aspek solvabilitas yang diukur dengan rasio Debt Ekuity Ratio (DER) maupun dari aspek profitabilitas yang diukur dengan rasio Retrun On Assets (ROA).

Implikasi penelitian bahwa nilai solvabilitas (DER) yang tinggi dan nilai profitablitas (ROA) yang rendah hal ini jika terus berkepanjangan maka akan berdampak pada menurunnya tingkat kepercayaan kreditur atau calon kriditur dan investor atau calon investor terhadap perusahaan,
\end{abstract}

Kata kunci : Kinerja keuangan, solvabilitas, profitabilitas, pandemi covid

\section{Abstrack}

This study aims to analyze differences in financial performance from the aspects of solvency and profitability before and during the Covid pandemic. The research was conducted at PT Telkomsel. The data is collected using documentation techniques in the form of financial reports based on the first, second and third quarters of 2019 and 2020. The analysis technique uses the Different $t$ Test with the Paired Samples T Test, which compares data before the Covid pandemic (2019) with data during the Covid pandemic (2020).

The results showed that the solvency value (DER) during the Covid pandemic increased compared to before the Covid pandemic, while the profitability value (ROA) during the Covid pandemic decreased compared to before the Covid pandemic. Then there is a significant difference in financial performance before and during the Covid pandemic both from the solvency aspect as measured by the Debt Equity Ratio (DER) and from the profitability aspect as measured by the Retrun On Assets (ROA) ratio.

The research implication is that the high solvency value (DER) and the low profitability value (ROA), if it continues to be prolonged, will have an impact on decreasing the level of trust of creditors or potential creditors and investors or potential investors in the company.

Keywords: financial performance, solvency, profitability, covid pandemic

\section{PENDAHULUAN}

Pandemi virus corona di akhir tahun 2019 yang lalu tentunya sangat berdampak terhadap tatanan kehidupan masyarakat dunia dalam berbagai aspek terutama kesehatan, ekonomi dan transportasi. Kebijakan pembatasan sosial atau karatina wilayah menjadikan mobilisasi masyarakat dalam menggerakkan roda perekomian menjadi terbatas, sehingga daya beli masyarakat menjadi menurun dan perekonomian menjadi stagnan (Shen et al., 2020). Dampak pandemi covid mengakibat banyak perusahaan 
mengalami penurunan profit yang sangat drastis. Namun, hal ini berbeda dengan perusahaan yang bergerak pada sektor telekomunikasi, di mana perusahaan ini masih memiliki daya tahan yang cukup baik ditengah-tengah masa pandemi covid-19. Kebutuhan masyarakat terhadap gaya hidup digital dengan akses data internet selama masa pandemi covid-19 turut meningkatkan kinerja emiten telekomunikasi. Pada kuartal II tahun 2020 pengguna internet di Indonsia mencapat 196 juta pengguna dari total populasi Indonesia sebesar 266 juta jiwa. Jika dibandingkan dengan tahun 2018 sebanyak 171 juta pengguna, sehingga kenaikan sebesar 8,9 persen atau sekitar 25,5 juta pengguna (Kompas.com, 2020). Peningkatan pengguna internet tersebut dapat meningkatkan pendapatan dan laba pada beberapa perusahaan, namun di perusahaan lain terjadi penurunan omset penjualan dan laba. Pandemi Covid tidak selamanya berdampak buruk pada kinerja keuangan perusahaan, akan tetapi berapa perusahaan akan mengalami kinerja keuangan yang baik (Ali, 2020). Data laporan keuangan beberapa perusahaan Telekomunikasi yang listing pada Bursa Efek Indonesia pada kuartal ketiga tahun 2019 dan 2020 sebagai berikut:

\section{Tabel 1}

Pendapatan dan Laba Beberapa Perusahaan Sektor Telekomunikasi. (dalam milyaran rupiah)

\begin{tabular}{|c|c|c|c|}
\hline Perusahaan & Periode & Penjualan & $\begin{array}{c}\text { Laba Setelah } \\
\text { Pajak }\end{array}$ \\
\hline \multirow{2}{*}{ PT Telkomsel Tbk. } & 31 September 2019 & 102,631 & 23,200 \\
\hline & 30 September 2020 & 99,941 & 22,951 \\
\hline \multirow{2}{*}{ PT XL Axianta Tbk. } & 31 September 2019 & 18,720 & 498 \\
\hline & 30 September 2020 & 19,656 & 2,075 \\
\hline \multirow{2}{*}{$\begin{array}{l}\text { PT Smartfren } \\
\text { Telecom Tbk. }\end{array}$} & 31 September 2019 & 4,978 & $(1,639)$ \\
\hline & 30 September 2020 & 6,845 & $(1,751)$ \\
\hline \multirow{2}{*}{ PT Indosat Tbk. } & 31 September 2019 & 18,853 & (418) \\
\hline & 30 September 2020 & 20,592 & (256) \\
\hline
\end{tabular}

Sumber : Data Olahan Tahun 2021

Berdasarkan data pada tabel 1.1 menunjukkan bahwa kinerja keuangan dalam hal ini laba pada perusahaan industri Telekomunikasi berfluktuasi. Di mana terjadi peningkatan dan penurunan penjualan dan laba sepanjang periode September 2019 dan September 2020, di mana pada September 2019 sebelum adanya Covid 19 dan September 2020 merupakan data selama Covid 19. Pada PT Telkomsel terjadi penurunan pendapatan/penjualan dan laba selama covid (2020) dibanding dengan sebelum ada pandemi Covid (2019). Penurunan pendapatan/penjualan pada PT Telkomsel ini dikarenakan PT Telkomsel menawarkan harga jual produk lebih tinggi dibandingkan dengan yang tawarkan oleh provider lain, sehingga banyak pelanggan beralih ke provaider yang lain. Hal ini merupakan salah satu faktor menurunnya penjualan PT Telkomsel. Kondisi demikian mengharuskan manajemen PT TELKOMSEL secara terus menerus melakukan evaluasi terhadap kinerjanya dan kemudian menyusun langkah-langkat strategis untuk mengembangkan perusahaan di masa yang akan datang. Salah satu yang perlu dievaluasi adalah mengenai kinerja keuangan. Kinerja keuangan merupakan instrumen yang sangat penting bagi suatu perusahaan, karena menjadi alat ukur untuk mengetahui proses pelaksanaan sumber 
daya keuangan suatu perusahaan. Pengukuran terhadap kinerja keuangan menjadi penting karena kinerja keuangan menjadi alat penilaian investor dan kreditor dalam menganalisis perkembangan keuangan perusahaan dalam rangka mengambil keputusan investasi. Pencapaian kinerja keuangan yang baik akan meningkatkan kepercayaan investor nilai perusahaan dan hal ini akan berdampak terhadap meningkatnya nilai saham (Achmad \& Amanah, 2014).

Beberapa penelitian yang terkait dengan kinerja keuangan perusahaan sebelum dan selama covid masih menunjukkan hasil yang kontradiktif. Hasil penelitian (Riftiasari \& Sugiarti, 2020) menunjukkan tidak terdapat perbedaan yang signifikan kenerja keuangan antara Bank BCA Konvesional dan Bank BCA Syariah selama pandemi Covid-19. Hal ini berbeda dengan penelitian yang dilakukan oleh (Ilhami \& Thamrin, 2021) bahwa keseluruhan dampak Covid-19 terhadap kinerja keuangan perbankan syariah di Indonesia tidak signifikan menunjukan adanya perbedaan kinerja keuangan. Kemudian penelitian (Surya \& Asiyah, 2020) bahwa terdapat perbedaan antara kinerja keuangan Bank BNI Syariah dan Bank Syariah Mandiri dari aspek ROA, NPF dan BOPO, dan sedangkan dari segi aspek CAR dan ROE menunjukkan bahwa secara signifikan tidak ada perbedaan antara kinerja keuangan pada kedua Bank tersebut. Dan penelitian (Fitriani, 2020).

Pengukuran kinerja keuangan dilakukan melalui analisis laporan keuangan. Rasio keuangan merupakan alat utama dalam melakukan analisa keuangan (Harrison et al., 2013). Sehingga tujuan utama yang ingin dicapai dalam melakukan analisa laporan keuangan adalah untuk menilai kinerja perusahaan dalam usaha mencapai hasil yang optimal demi kelangsungan usaha (Utami \& Pardanawati, 2016). Rasio keuangan akan membantu investor dalam mengevaluasi perusahaan, sehingga para investor tidak berspekulasi dalam menilai kinerja perusahaan berdasarkan rasio keuangan tersebut (Nalurita, 2017). Terdapat terdapat tiga karakteristik yang dievaluasi melalui analisis laporan keuangan yaitu likuiditas, solvabilitas dan profitabilitas. Untuk menilai kemampuan perusahaan untuk bertahan dalam jangka waktu lama dan kemampuan dalam membayar deviden dan pertumbuhan investasi maka pemegang saham lebih tertarik pada solvabilitas dan profitabilitas (Weygandt et al., 2018).

Rasio solvabilitas atau diistilahkan dengan rasio utang adalah kemampuan perusahaan dalam memenuhi semua kewajibannya baik kewajiban jangka pendek maupun kewajiban jangka panjang (Harrison et al., 2013). Menurut (Kariyoto, 2017) menjelaskan bahwa terdapat beberapa kepentingan kreditor terhadap suatu perusahaan yaitu (a) kemampuan membayar bunga dan pokok pinjaman, (b) kebijakan perlindungan kreditur jangka panjang dan (c) prospek laba dan perkiraan arus kas. Sehingga rasio yang dapat digunakan untuk mengukur solvabilitas adalah Debt to Ekuity Rasio (DER). Rasio ini untuk mengukur proporsi aset yang didanai oleh kreditur dan didanai oleh pemilik perusahaan. Semakin kecil DER menunjukkan makin besar total aset didanai oleh modal sendiri dan semakin besar menopang risiko kreditur. Sehingga pada umumnya kreditur lebih menyukai angka DER yang rendah. Menurut (Fajri, 2018) bahwa DER menggambarkan sejauhmana kemampuan pemilik modal dalam membayar kewajiban pada pihak luar (kreditur). Rumus untuk mengukur DER adalah (Kariyoto, 2017) :

$$
\text { Debt to Ekuity Rasio }(\mathrm{DER})=\frac{\text { Total Aset }}{\text { Total Ekuity }}
$$


Rasio profitabilitas adalah rasio digunakan untuk mengukur kemampuan perusahaan untuk menghasilkan laba dalam kondisi normal perusahaan dengan menggunakan kemampuan aset yang dimiliki melalui penjualan aset, kemampuan aset dan kemampuan modal. Rasio profitabilitas memberikan manfaat terhadap pihak-pihak yang berkepentingan terhadap perusahaan, diantaranya adalah untuk mengukur jumlah laba bersih yang dihasilkan dari setiap rupiah yang terinvestasi dari total aset. Dengan demikian salah satu rasio yang sering digunakan untuk mengukur profitabilitas adalah Return On Assets (ROA). Semakin tinggi ROA semakin tinggi pula jumlah laba bersih yang dihasilkan dari setiap rupiah yang ditanamkan dalam total asset perusahaan (Hery, 2016). Rumus ROA sebagai berikut

$$
\text { Return On Assets }(\mathrm{ROA})=\frac{\text { Laba bersih }}{\text { Total Aset }}
$$

Tujuan yang ingin dicapai dalam penelitian ini untuk menganalisis perbedaan kinerja keuagan dari aspek solvabilitas dan proftabilitas sebelum dan selama pandemi covid pada PT Telkomsel. Analisis ini perlu dilakukan sehingga bisa diketahui apakah perbedaan tersebut signifikan atau tidak. Sehingga dengan analisis tersebut diharapkan dapat memberikan informasi kepada pihak-pihak yang berkepentingan terutama investor dan kreditor dalam mengambil keputusan yang terkait dengan perusahaan.

\section{METODE PENELITIAN}

Penelitian ini merupakan penelitian dengan pendekatan kuantitatif dan dari jenisnya merupakan penelitian replikatif, yakni melakukan pengujian ulang terhadap hasil-hasil penelitian sebelumnya pada lokasi atau kondisi yang berbeda (Ferdinand, 2011). Penelitian ini diakukan pada perusahaan PT Telekomsel, Tbk dengan mengunjungi www.idx.co.id. Waktu penelitian dilakukan kurang lebih 2 bulan yang di mulai sejak awal Februari hingga akhir Maret 2021. Sasaran penelitian terkait dengan pengukuran kinerja keuangan dari aspek solvabilitas dan profitabilitas sebelum dan selama pandemic Covid pada PT Telkomsel. Subjek penelitian adalah data laporan posisi keuangan dan laporan laba rugi kuartal pertama, kedua dan ketiga tahun 2019 dan 2020 pada PT Telkomsel.

Penelitian ini diawali dengan ada fenomena berupa data pencapaian laba dari beberapa perusahaan telekomunikasi pada masa pandemi Covid yang berfluktuasi dan juga beberapa hasil penetian yang kontradiktif yang terkait perbandingan kinerja keuangan sebelum dan selama pandemic Covid. Berdasarkan data dan kontradiksi hasil penelitian sebelumnya kemudian ditemukan dan dirumuskan masalah penelitian. Selanjutnya dilakukan kajian pustaka secara teoritis dan empiris yang relevan dengan masalah penelitian. Kemudian dirumuskan hipotesis. Kemudian dilakukan pengumpulan data, pengujian data dan analisis data untuk menguji hipotesis dan ditarik kesimpulan penelitian.

\section{Instrumen dan Operasional Variabel}

Instrumen penelitian berupa analisis dokumen yang disusun berdasarkan indikator variabel. Operasional variabel dapat dijelaskan pada tabel berikut ini : 


\section{AkMen

Tabel 2 :

Operasional variabel

\begin{tabular}{|c|c|c|c|}
\hline No & Variabel & Indikator & Skala \\
\hline
\end{tabular}

Rasio Debt to Ekuity (DER

1 Solvabilitas

$(\mathrm{DER})=\frac{\text { Total Aset }}{\text { Total Ekuity }}$

Skala

Rasio

Sumber (Kariyoto, 2017)

Retur On Aset (ROA)

$\begin{array}{ll}\text { (ROA })=\frac{\text { Laba bersih }}{\text { Total Aset }} & \text { Skala } \\ \text { Rasio }\end{array}$

2 Profitabilitas

Sumber (Hery, 2016)

\section{Teknik Analisis Data}

Untuk mengukur dan menganalisis perbandingan kinerja keuangan dari aspek solvabilitas dan profitabilitas digunakan Uji Beda $t$ test dengan jenis pengujian Paired Samples T Test, yaitu menguji hipotesis dua mean yang berhubungan (Sekaran \& Bougie, 2017). Sehubungan dengan penelitian ini adalah menguji perbedaan kinerja keuangan dari aspek solvabilitas dan profitabilitas sebelum dan selama Covid 19 pada perusahaan PT Telekomsel.

\section{HASIL DAN PEMBAHASAN \\ Hasil}

Analisis tentang aspek rasio solvabilitas dan proftabilitas untuk mengukur kinerja keuangan PT Telkomsel sebelum dan selama pandemi covid dapat dijelaskan bahwa dalam penelitian ini aspek solvabilitas diukur dengan menggunakan Debt Equity Ratio (DER) dan aspek profitabilitas dengan ukur dengan Return On Assets (ROA). Data yang dianalisis data data laporan keuangan kuartal kesatu, kedua dan ketiga tahun 2019 diasumsikan sebagai data sebelum pandemi covid dan data laporan keuangan kuartal kesatu, kedua dan ketiga tahun 2020 sebagai data selama pandemi covid. Hasil analisis data dapat dijabarkan pada tabel berikut ini :

Tabel 3

Perhitungan Solvabiitas dan Profitabilitas PT Telkomsel, Tbk

\begin{tabular}{ccccc}
\hline \multirow{2}{*}{ KUARTAL } & \multicolumn{2}{c}{ SOLVABILITAS (DER) } & \multicolumn{2}{c}{ PROFITABILITAS (ROA) } \\
\cline { 2 - 5 } & $\begin{array}{c}\text { SEBELUM } \\
\text { COVID (2019) }\end{array}$ & $\begin{array}{c}\text { SELAMA } \\
\text { COVID (2020) }\end{array}$ & $\begin{array}{c}\text { SEBELUM } \\
\text { COVID 2019) }\end{array}$ & $\begin{array}{c}\text { SELAMA } \\
\text { COVID (2020) }\end{array}$ \\
\hline 1 & $74,01 \%$ & $91,17 \%$ & $3,88 \%$ & $3,32 \%$ \\
\hline 2 & $99,09 \%$ & $123,38 \%$ & $7,19 \%$ & $6,27 \%$ \\
\hline 3 & $84,63 \%$ & $97,83 \%$ & $10,79 \%$ & $9,83 \%$ \\
\hline
\end{tabular}




\section{AkMen \\ Volume 18 Nomor 2 Agustus 2021 \\ Hal. 135-143 \\ e-ISSN : 2621-4377 \& p-ISSN : 1829-8524 \\ Hbmepage: https//e-jurnal.nobel.acid/indexphp/akmen}

\begin{tabular}{ccccc}
\hline \multirow{2}{*}{ KUARTAL } & \multicolumn{2}{c}{ SOLVABILITAS (DER) } & \multicolumn{2}{c}{ PROFITABILITAS (ROA) } \\
\cline { 2 - 5 } & $\begin{array}{c}\text { SEBELUM } \\
\text { COVID (2019) }\end{array}$ & $\begin{array}{c}\text { SELAMA } \\
\text { COVID (2020) }\end{array}$ & $\begin{array}{c}\text { SEBELUM } \\
\text { COVID 2019) }\end{array}$ & $\begin{array}{c}\text { SELAMA } \\
\text { COVID (2020) }\end{array}$ \\
\hline Rata-Rata & $85,91 \%$ & $104,12 \%$ & $7,28 \%$ & $6,42 \%$ \\
\hline
\end{tabular}

Sumber : Data diolah tahun 2021

Berdasarkan data pada tabel 3 tersebut menggambarkan bahwa rasio solvabilitas (DER) sebelum pandemi covid (2019) pada kuartal 1 sebesar 74,01\% kemudian pada kuartal yang sama selama pandemi covid (2020) meningkat menjadi 91,17\%. Demikian juga pada kuartal kedua sebelum covid sebesar 99,09\% dan selama pandemic covid sebesar 123,38\% dan pada kuartal ketiga sebelum pandemi covid sebesar 84,63\% dan meningkat menjadi $97,83 \%$ selama pandemi covid pada kuartal yang sama. Kemudian rata DER sebelum pandemi covid sebesar $85,91 \%$ dan selama pandemi covid sebesar $104,12 \%$. Selanjutnya dari aspek profitabilitas (ROA) menunjukkan bahwa pada kuartal pertama sebelum pandemi covid (2019) nilai ROA sebesar 3,88\% namun selama pandemi covid menurun menjadi 3,32\%. Pada kuartal kedua sebelum pandemi covid nilai ROA sebesar $7,19 \%$ dan selama pandemi covid menurun menjadi $6,27 \%$. Kemudian pada kuartal ketiga nilai ROA sebesar $10,79 \%$ sebelum pandemi covid tetapi selama pandemi covid pada kuartal ketiga menurun sebesar 9,83\%. Dan rata-rata nilai ROA sebelum pandemi covid sebesar 7,28\% dan selama pandemi covid menjadi $6,43 \%$. Dari uraian tersebut menunjukan terdapat perbedaan kinerja kinerja keuangan sebelum dan selama pandemi covid. Kemudian untuk mengetahui perbedaaan kinerja keuangan keuangan dari aspek solvabilitas dan profitabilitas sebelum dan selama pandemi covid signifikan atau tidak maka dilakukan pengujian dengan menggunakan Uji Beda t test dengan jenis pengujian Paired Samples T Test. Hasil pengujian dapat dilihat dalam tabel berikut ini :

Tabel 4

Uji Paired Samples T Test

\begin{tabular}{clccc}
\hline $\begin{array}{c}\text { Aspek Kinerja } \\
\text { Keuangan }\end{array}$ & Paired Samples T Test & Mean & t & $\begin{array}{c}\text { Sig } \\
\text { (2 tailed) }\end{array}$ \\
\hline Solvabilitas (DER) & $\begin{array}{l}\text { DER Sebelum Covid - } \\
\text { Selama Covid }\end{array}$ & $-18,21$ & $-5,614$ & 0,030 \\
& & & & \\
\hline Profitabilitas (ROA) & $\begin{array}{l}\text { ROA Sebelum Covid - } \\
\text { Selama Covid }\end{array}$ & 0,81 & 6,395 & 0,024 \\
& & & &
\end{tabular}

\section{Sumber : Data diolah tahun 2021}

Berdasarkan data pada tabel dapat dijelaskan bahwa pada PT Telkomsel memiliki nilai rata DER sebelum dan selama Covid bertanda negatif sebesar -18,21, nilai t hitung bertanda negatif sebesar $-5,614$ dan nilai signifikan 0,03. Kemudian nilai rata-rata ROA sebelum dan selama Covid sebesar 0,81, nilai t hitung sebesar 6,395 dengan nilai signifikan sebesar 0,024 .

\section{Pembahasan}

Perbedaan Kinerja Keuangan Sebelum Dan Selama Pandemi Covid dari Aspek Sovabilitas 
Berdasarkan hasil analisis nilai DER sebagai alat ukur tingkat sovabilitas menunjukkan nilai DER sebelum pendemi covid (2019) untuk setiap kuartal mengalami perubahan yang berfluktuasi di mana pada kuartal pertama nilai DER lebih rendah dibanding dengan kuartal kedua, dengan kata lain nilai DER pada kuartal kedua meningkat jika dibandingkan dengan kuartal pertama, namun pada kuartal ketiga terjadi penurunan nilai DER. Hal ini juga terjadi selama pandemi covid (2020) nilai DER mengalami fluktuasi perubahannya, di mana pada kuartal kedua terjadi peningkatan namun pada kuartal ketiga terjadi penurunan. Akan tetapi jika dibandingkan nilai DER sebelum dan selama pandemi covid mengindikasikan nilai DER yang konsitsen yakni selama pandemi covid nilai DER lebih tinggi dibandingkan dengan nilai DER sebelum pandemi covid, baik secara kuartal maupun nilai rata-rata DER.

Kemudian pengujian tingkat signifikan menunjukkan terjadi perbedaan yang signikan kinerja keuangan dari aspek solvabilitas (DER) sebelum dan selama pandemi covid. Hal ini dilihat pengujian Paired Samples T Test diketahui nilai signifikan solvabilitas/DER $(0,03)$. Nilai ini lebih kecil dari 0,05 . Sehingga dapat dikatakan terdapat perbedaan yang signifikan kinerja keuangan dari aspek solvabiliitas sebelum dan selama covid. Hasil penelitian ini mendukung penelitian yang dilakukan oleh (Riftiasari \& Sugiarti, 2020).

Rasio DER digunakan untuk mengukur sejauhmana kemampuan perusahaan membayar kewajiban (utang) pada kreditur. Nilai DER yang tinggi selama pandemi covid dibandingkan dengan sebelum covid menggambarkan selama pandemi covid terjadi peningkatan pembayaran kewajiban (utang) PT Telkomsel kepada pihak ketiga (kreditur) dengan menggunakan modal sendiri. Kondisi kinerja keuangan yang demikian (nilai DER yang tinggi) dari sudut pandang kreditur atau calon kreditur merupakan suatu hal yang kurang baik. Karena semakin nilai DER semakin kecil modal sendiri dalam menopang risiko kredit. Pada umumnya para kreditur atau calon kreditur menginginkan nilai DER yang rendah. Semakin kecil DER menunjukkan makin besar total aset didanai oleh modal sendiri dan semakin besar menopang risiko kreditur (Fajri, 2018).

\section{Perbedaan Kinerja Keuangan Sebelum Dan Selama Pandemi Covid dari Aspek Sovabilitas}

Profitabilitas dalam penelitian ini diukur dengan menggunakan Return On Assets Ratio (ROA). Berdasakan hasil analisis menunjukkan sebelum pendemi covid (2019) nilai ROA mengalami peningkatan antar kuartal. Demikian juga selama pandemi Covid (2020). Namun, jika dibandingkan sebelum dan selama pandemi covid menunjukan nilai ROA selama pandemi covid mengalami penurunan dibanding dengan sebelum pandemi covid.

Kemudian perbandingan profitabilitas sebelum dan selama pandemi covid menunjukan perbedaan yang signifikan. Hal ini dilihat berdasarkan pengujian Paired Samples T Test diketahui nilai signifikan profitabilitas/ROA $(0,024)$. Nilai ini lebih kecil dari 0,05. Sehingga dapat dikatakan terdapat perbedaan yang signifikan kinerja keuangan dari aspek profitabilitas sebelum dan selama covid. Hasil penelitian mendukung penelitian yang dilakukan oleh (Riftiasari \& Sugiarti, 2020) dan (Surya \& Asiyah, 2020).

Rasio profitabilitas/ROA menggambarkan kemampuan perusahaan untuk menghasilkan laba dari setiap rupiah yang terinvestasi dari total aset. Nilai ROA yang selama pandemi covid dibandingkan demgan sebelum pandemi covid menunjukkan 
bahwa selama pandemi covid kemampuan perusahaan PT Telkomsel dalam memperoleh laba (profit) menurun di setiap kuartal. Pihak-pihak yang berkepentingan terhadap perusahaan misalnya investor atau calon investor mengingkan nilai ROA yang tinggi. Semain tinggi nilai ROA semakin tinggi pula jumlah laba bersih yang dihasilkan dari setiap rupiah yang ditanamkan dalam total asset perusahaan (Hery, 2016). Meningkatnya nilai ROA akan berimplikasi terhadap pembayaran deviden yang tinggi.

\section{KESIMPULAN}

Simpulan penelitian bahwa (1) nilai solvabilitas (DER) selama pandemi covid meningkat dibanding sebelum pandemi covid, sedangkan nilai profitabilitas (ROA) selama pandemi covid menurun dibanding sebelum pandemi covid. (2). Terdapat perbedaan yang signifikan kinerja keuangan PT sebelum dan selama pandemi covid baik dari aspek solvabilitas yang diukur dengan rasio Debt Ekuity Ratio (DER) maupun dari aspek profitabilitas yang diukur dengan rasio Retrun On Assets (ROA).

\section{REKOMENDASI}

Sehubungan dengan simpulan tersebut maka rekomendasi penelitian agar manajemen perusahaan PT Telkomsel perlu mengambil kebijakan strategis dalam rangka menurunkan nilai solvabilitas (DER) dan meningkatkan profitabilitas (ROA). Hal ini sebagai upaya untuk meningkatkan kepercayaan investor atau calon investor dan kreditur atau calon kreditor terhadap kenerja perusahaan.

\section{KETERBATASAN PENELITIAN}

Penilitian ini masih terbatas menggunakan rasio kinerja keuangan, yakni untuk aspek sovabilitas diukur dengan menggunakan rasi DER sedangkan untuk profitabilitas mengunakan rasio ROA. Dengan demikian peneliti selanjutnya dapat menggunakan beberapa rasio keuangan sehingga pengukuran kinerja keuangan lebih komplit dan lebih objektif.

\section{DAFTAR PUSTAKA}

Achmad, S. L., \& Amanah, L. (2014). Pengaruh Investasi,Keputusan Pendanaan,Kebijakan Dividen,Dan Kinerja Keuangan Terhadap Nilai Perusahaan manufaktur yang terdaftar di Bursa Efek Indonesia selama periode 2010-2012. Jurnal Ilmu \& Riset Akuntansi, 3(9), 1-15. https://rudiyanto.id/wpcontent/uploads/2020/02/keputusan-investasi-thd-kinerja.pdf

Ali, I. (2020). A study on impact of GST on Indian economy. International Research Journal of Modernization in Engineering Technology and Science, 02(07), 279283. www.irjmets.com

Fajri, G. R. (2018). The Effect of Rentability Ratio, Solvability Ratio, Liquidity Ratio upon the Company's Value (Emperical Study of Mining companies Sub Sector of Metal and Other Mineral Registered in The Indonesia Stock Exchange in 2012 2016). The Accounting Journal of Binaniaga, 3(1), 39. https://doi.org/10.33062/ajb.v3i1.176

Ferdinand, A. (2011). Metode Penelitian Manajemen. Badan Penerbit Universitas 
Diponegoro.

Fitriani, P. D. (2020). Analisis Komparatif Kinerja Keuangan Bank Umum Syariah Pada Masa Pandemi Covid-19. Jurnal Ilmu Akuntansi Dan Bisnis Syariah, II(113124).

Harrison, W. T., Horngren, C. T., Thomas, C. W., \& Suwardy, T. (2013). Akuntansi Keuangan: International Financial Reporting Standars - IFRS (Edisi 8). PT Erlangga.

Hery. (2016). Analisis Laporan Keuangan: Integrated and Comprehensive Edition (Adiparamono (ed.)). PT Grasindo.

Ilhami, \& Thamrin, H. (2021). Analisis Dampak Covid 19 Terhadap Kinerja Keuangan Perbankan Syariah Di Indonesia. Jurnal Tabarru': Islamic Banking and Finance, 4(1), 37-45. https://doi.org/10.25299/jtb.2021.vol4(1).6068

Kariyoto. (2017). Analisa Laporan Keuangan (Tim UB Press (ed.); Cetakan Pe). UB Press.

Kompas.com. (2020). Pengguna Internet Indonesia hingga Kuartal II 2020 Capai 196,7 $\begin{array}{llll}\text { Juta Orang. } & \text { Kompas.Com, } 09 & \text { November } & \end{array}$ https://money.kompas.com/read/2020/11/09/213534626/pengguna-internetindonesia-hingga-kuartal-ii-2020-capai-1967-juta-orang

Nalurita, F. (2017). the Effect of Profitability Ratio, Solvability Ratio, Market Ratio on Stock Return. Business and Entrepreneurial Review, 15(1), 73. https://doi.org/10.25105/ber.v15i1.2080

Riftiasari, D., \& Sugiarti. (2020). Analisis Kinerja Keuangan Bank Bca Konvesional Dan Bank Bca Syariah Akibat Dampak Pandemi Covid-19. Jurnal Manajemen Bisnis, 33(2), 78-86.

Sekaran, U., \& Bougie, R. (2017). Metode Penelitian untuk Bisnis. Salemba Empat.

Shen, H., Fu, M., Pan, H., Yu, Z., \& Chen, Y. (2020). The Impact of the COVID-19 Pandemic on Firm Performance. Emerging Markets Finance and Trade, 56(10), 2213-2230. https://doi.org/10.1080/1540496X.2020.1785863

Surya, Y. A., \& Asiyah, B. N. (2020). Analisis Perbandingan Kinerja Keuangan Bank BNI Syariah dan Bank Syariah Mandiri di Masa Pandemi Covid-19. Jurnal Ekonomi Dan Perbankan Syariah, 7(2), 170-187. https://doi.org/10.1905/iqtishadia.v7i2.3672

Utami, W. B., \& Pardanawati, S. L. (2016). Pengaruh Likuiditas, Solvabilitas, Dan Manajemen Aset Terhadap Kinerja Keuangan Pada Perusahaan Go Publik Yang Terdaftar Dalam Kompas 100 Di Indonesia. Jurnal Akuntansi Dan Pajak, 17(01), 63-72. https://doi.org/10.29040/jap.v17i01.58

Weygandt, J. J., Kimmel, P. D., \& Kieso, D. E. (2018). Pengantar Akuntansi 2 : Berbasis IFRS (Edisi 2). Salemba Empat. 